\title{
KOMUNIKATYWNO-PRAGMATYCZNY ASPEKT CZERWIENI (NA PRZYKŁADZIE KSIĄŻKI У ВОЙНЫ НЕ ЖЕНСКОЕ ЛИЦО SWIETŁANY ALEKSIJEWICZ)
}

\author{
THE COMMUNICATIVE AND PRAGMATIC ASPECTS \\ OF THE COLOUR RED (BASED ON SVETLANA ALEXIEVICH'S NOVEL \\ WAR DOES NOT HAVE A WOMAN'S FACE)
}

\section{DARIA SEUPIANEK-TAJNERT}

\begin{abstract}
Aвstract. The article presents the role of the colour red in defining two communicative and pragmatic centres (the war and the woman) in Svetlana Alexievich's reportage War Does Not Have a Woman's Face. The colour red plays a significant role in visualizing war events and depicting different aspects of female sensitivity.
\end{abstract}

Keywords: red, pragmatics, communication, functions of language

Daria Słupianek-Tajnert, Uniwersytet im. Adama Mickiewicza w Poznaniu, Poznań Polska, daria.slupianek@amu.edu.pl

ORCID ID: 0000-0002-4339-1852

Swietłana Aleksijewicz, białoruska pisarka, którą w 2015 roku Akademia Szwedzka doceniła i uhonorowała za mistrzostwo reportażu literackiego, znana jest przede wszystkim z książek poruszających problematykę newralgicznych punktów historii Związku Radzieckiego, takich jak katastrofa reaktora atomowego w Czarnobylu (Чернобыльская молитва, pol. Czarnobylska modlitwa), radziecka interwencja w Afganistanie (Цинковые мальчики, pol. Cynkowi chłopcy), uczestnictwo kobiet w drugiej wojnie światowej ( $У$ войны не женское лицо, pol. Wojna nie ma w sobie nic z kobiety), losy dzieci w czasie wojny [Последние свидетели (сто недетских рассказов), pol. Ostatni świadkowie. (Utwory solowe na głos dziecięcy)] czy codzienność ludzi po upadku systemu komunistycznego (Время секонд хэнд, pol. Czasy secondhand. Koniec czerwonego człowieka).

Andrzej Stasiuk, poproszony o komentarz dotyczący cech charakterystycznych i wyróżników twórczości noblistki, podkreślił, że jest to „kobieca czułość dla świata, wrażliwość - czasami aż czytelniczo nieznośna, czujność, czułość" [Literacki Nobel 2015 dla Swiettany Aleksijewicz 2015]. Ten nazwany przez Stasiuka kobiecy pierwiastek w twórczości Aleksijewicz jest wszechobecny, zaś w szczególnie namacalny sposób wyeksponowany został w jej 
pierwszej książce $У$ войны не женское лицо, zawierającej opis wojny widziany oczami kobiet - uczestniczek Wielkiej Wojny Ojczyźnianej. Pełniły podczas niej różne role - pracowały zarówno na tyłach, jak i walczyły na pierwszej linii, były sanitariuszkami, zwiadowczyniami, snajperkami, czołgistkami.

Sama autorka mówi w nawiązaniu do powyższej książki: „Wojna nie ma ludzkiej twarzy. Ale ja patrzę na wojnę oczami kobiet. Daję im prawo głosu, aby opowiedziały o swojej kobiecej wojnie, a nie o męskiej. Kobieta pamięta co innego, inaczej pamięta. Pamięta kolor, zapach, ma dużo uczuć, których nie mają mężczyźni. Kobiety pamiętają więcej swoich emocji" [Ostałowska 2011].

„Przez trzydzieści lat pisałam encyklopedię czerwonej utopii" [Kutrzuba 2015] - powiedziała Aleksijewicz na 7. Festiwalu Conrada w Krakowie. „Sama jestem czerwonym człowiekiem” [2015] - mówi laureatka literackiej Nagrody Nobla w jednym z kolejnych wywiadów. Kolor czerwony jest stale obecny w twórczości noblistki. Jest to kolor, który na tle innych koloratywów odegrał przypuszczalnie największą symboliczną rolę w rzeczywistości sowieckiej, a w kontekście przypadającej w 2017 roku setnej już rocznicy rewolucji październikowej, tym bardziej wydaje się być tematem na nowo aktualnym. Czerwień na tle czasów sowieckich jawi się jako swoiste narzędzie komunikacji, posiadające ogromną siłę przekazu. Ta siła przekazu jest też wyjątkowo odczuwalna na płaszczyźnie tematyki wojennej, którą porusza reportaż $У$ войны не женское мицо.

Czerwień ma olbrzymi potencjał konotacyjny. Kolor ten był jednym z bodźców w przeprowadzonym pod patronatem Rosyjskiej Akademii Nauk międzynarodowym eksperymencie asocjacyjnym, którego cel stanowiło określenie pól asocjacyjnych wyrazów-bodźców ${ }^{1}$. Analiza wyników dotyczących bodźca красный wśród rosyjskich badanych pozwoliła zgromadzić następujące dane:

красный²: флаг 15; свет 11; цвет 8; галстук 7; помидор 4; квадрат, нос, перец, шар 3; белый, комиссар, петух, светофор 2; автобус, бант, бог, богатырь, большевик, голубой, губы, желтый, зеленый, как кровь, как рак, кафтан, кирпич, командир, комбинезон, коммунист, красиво, красивый, кровавый, ласковый, мак, мальчик, огонь, Октябрь, от стыда, плащ, площадь, раздражение, революция, рот, солнце, уголок, флот, черный, член, шарик, шарф, яркий 1; 104+51+1+38 [Караулов, Черкасова, Уфимцева, Сорокин, Тарасов 2002: 275].

${ }^{1}$ Wyniki tego eksperymentu dotyczące koloratywów biaty, czarny, czerwony, zielony w języku rosyjskim i polskim referuje Izabela Pietrzyk [2008].

2 Obok słowa-bodźca zamieszczone są wszystkie słowa-reakcje według częstotliwości ich pojawiania się. Liczby podane na końcu hasła to kolejno: liczba badanych, którzy zareagowali na dany bodziec; liczba różnych słów-reakcji; liczba badanych, którzy nie udzielili odpowiedzi; liczba reakcji pojedynczych. 
Z kolei na gruncie polskim wyniki przedstawiały się następująco:

czerwony: kolor 91; krew 74; zielony 60; ogień 21; mak 17; kapturek 14; niebieski 11; seks, serce 10; miłość 9; biały, czarny, pomidor, róża 8; kwiat 6; burak, jabłko, światło, wojna 5; flaga, krwisty, żar 4; biedronka, cegła, ciepło, gorący, komunizm, krzyż, sweter, wino, zakaz 3; agresja, cierpienie, księżyc, kur, październik, Rosja, słońce 2; agresywny, autobus, balon, barszcz, beret, bielizna, bluzka, domek, film Kieślowskiego, gorąco, impulsywny, intensywny, jak cegła, kabaret, kartka, koc, kolor komunistyczny, kolor miłości, kolor serca, komuch, komunista, korale, krawat, krwią, latarnia, litera, ładny kolor, Mikołaj, mocny, muchomor, namiętność, napis, nie idź, nos, ogród, ostry, pająk, papryka, pewność siebie, plecak, pokój, polik, polityka, pożądanie, prostytutka, red, rezerwa, rumienić się, samochód, siła, spódnica, Stalin, sztandar, św. Mikołaj, uwaga!, wrażliwość, wstęga, wstyd, wściekły, wzburzenie, zapach, zawstydzony, zło, złość, ZSRR, żółty, żywioł 1; 495+105+5+67 [Gawarkiewicz, Pietrzyk, Rodziewicz 2008: 41-42].

Nie analizując szczegółowo wszystkich przytoczonych asocjatów, warto jednak zwrócić uwagę na najczęściej pojawiające się słowo-reakcję w obu językach. Dla rosyjskojęzycznych uczestników badania najczęstszym pierwszym skojarzeniem z kolorem czerwonym okazało się słowo фłıaz, a wśród polskich badanych kolor. Jak podkreśla Izabela Pietrzyk, na gruncie rosyjskim mamy tutaj do czynienia z otwarciem "mitu komunizmu” [Pietrzyk 2008: 270], do którego nawiązali też swoimi odpowiedziami Polacy (skojarzenia typu: flaga, komunizm, październik, kolor komunistyczny, Stalin, ZSRR), jednak tego typu reakcje polskie były czterokrotnie rzadsze od rosyjskich $(17,2 \%$ wszystkich skojarzeń wśród Rosjan, 4,1\% wśród Polaków) [Pietrzyk 2008: 270]. W perspektywie dalszych rozważań zauważyć należy także wspólną dla Polaków i Rosjan, choć bardzo zróżnicowaną pod względem częstotliwości występowania, asocjację czerwieni z krwią.

Nie budzi sprzeciwu konstatacja, że komunikacja i interpretacja zawsze należą do sfery pragmatyki:

Употребление языковых знаков сопряжено с пониманием, с интерпретацией выраженных в них свидетельств. Герменевтический момент особенно важен потому, что идеальное языковое сообщество не ограничено лишь ныне живущими людьми, способными к непосредственному общению. Коммуникация захватывает всех, кто когда-либо пользовался языком и оставил какие-либо интерпретируемые свидетельства о себе [Тутнер 2009].

Oczywiste jest więc, że każdy utwór literacki, niezależnie od przynależności rodzajowej i gatunkowej, jest ukierunkowany na komunikację z czytelnikiem oraz na interpretację z jego strony. 
Nie ulega wątpliwości, że zrozumienie wypowiedzi nie może zaistnieć bez posiadanej wiedzy o świecie. Wiedza ta jest wielopłaszczyznowa i składają się na nią np. wiedza o sytuacji aktu mowy, elementy nieobecne w sytuacji mówienia, ale znane mówiącym, wiedza o świecie bazująca na doświadczeniu ogólnoludzkim, wiedza mająca swoje źródło w uczestnictwie we wspólnocie kulturowej mówiących (w tym w węziej rozumianej wspólnocie narodowej), wreszcie wiedza indywidualna, oparta na doświadczeniach jednostkowych [Grzegorczykowa 2010: 178-179]. Wiedza o świecie z każdego z wymienionych poziomów warunkuje znaczenie wyrazów i rozumienie wypowiedzi w ogóle. Poza wiedzą sferę pragmatyki dopełniają także doświadczenie, intencje osoby mówiącej oraz postawy psychiczne rozmówców.

Z pragmatyką łączą się również niektóre kluczowe pojęcia językoznawstwa kognitywnego. Nie można pominąć tutaj zjawiska konotacji polegającego na kojarzeniu pewnych cech i przeświadczeń w stosunku do nazywanych zjawisk. Asocjacje pełnią w językoznawstwie kognitywnym szczególną rolę, wspomnieć należy chociażby o wartości tego pojęcia dla definicji kognitywnej Jerzego Bartmińskiego czy też dla badań nad językowym obrazem świata. Asocjacje to także niezwykle ważny element w kontekście informacji przekazywanych pragmatycznie, a więc w oparciu o czynniki pozajęzykowe. Jak podkreśla Renata Grzegorczykowa, „[...] we współczesnym językoznawstwie zorientowanym kognitywistycznie pragmatyka zajmuje czołowe miejsce, usuwając $\mathrm{w}$ cień semantykę, $\mathrm{w}$ pewnym sensie utożsamiając się $\mathrm{z}$ nią. Kognitywiści kwestionują odróżnienie tych dwóch dziedzin jako osobnych obszarów badawczych" [Grzegorczykowa 2010: 177].

Na interdyscyplinarność współczesnej pragmatyki językowej zwraca również uwagę Piotr Cap. Podkreśla on, że jedną z podstawowych cech "pragmatyki kontynentalnej” (w odróżnieniu od „pragmatyki angloamerykańskiej”, opartej na warunkach prawdziwościowych) jest „nadrzędność badań uwarunkowanych społecznie, kognitywnie i kulturowo subiektywnych funkcji języka nad badaniami obiektywnej formy języka" oraz że program pragmatyki europejskiej „skanuje wszelkie zjawiska językowe pod kątem jakiejkolwiek, nawet śladowej, możliwości powiązania ich z pojęciem funkcji języka i jej oddziaływania społecznego w określonych warunkach kontekstowych" [Cap 2014: 161].

Niniejszy artykuł to próba refleksji nad rolą użycia koloru czerwonego jako istotnego elementu komunikacji w reportażu Aleksijewicz $У$ войны не женское мицо. Kolor czerwony zajmuje w nim miejsce szczególne. Pojawił się w tekście 60 razy. Oprócz tego w analizie uwzględniony został rzeczownik кровъ (poprzez który kolor czerwony przywołany został pośrednio 95 razy), $\mathrm{z}$ racji tego, że krew jest desygnatem bezpośrednio kojarzonym z barwą czer- 
woną. Uwzględniłam również derywaty покраснеть, кровавый oraz przymiotnik багровыü.

Aby uzmysłowić sobie dominację koloru czerwonego nad innymi pojawiającymi się w tekście utworu koloratywami, warto przywołać ilościowe dane porównawcze: przymiotnik белыu pojawia się w książce 57 razy, чеpный-52, зеленый-10, синий-8, желтый-6, серый-6, голубой-5, коричневый -1 .

Metatekstowy tytuł reportażu У войны не женское ^ицо wskazuje na dwa powiązane ze sobą centra komunikatywno-pragmatyczne utworu (rozumiane jako ośrodki koncentracji uwagi odbiorcy na określonych aspektach treści utworu), związane z jego tematyką - wojnę i kobietę. Tym dwóm centrom podporządkowane jest rozłożenie akcentów w reportażu i tymże centrom podporządkowane jest $\mathrm{w}$ dużej mierze funkcjonowanie $\mathrm{w}$ tekście koloratywu czerwony oraz bezpośrednio odnoszącego się do niego na płaszczyźnie asocjacyjno-kulturowej rzeczownika kpobъ.

Czynnik biolektalny, w szczególności płeć, przejawia się w reportażu na dwóch płaszczyznach. Z jednej strony prezentują go bohaterki książki - uczestniczki drugiej wojny światowej, z drugiej strony - sama autorka reportażu, która splata $\mathrm{w}$ zwartą całość opowieść $\mathrm{z}$ fragmentów przeprowadzonych wywiadów, w efekcie czego czytelnik percypuje polifoniczne świadectwo czasów wojennych, charakteryzujące się ogromną siłą prezentacji ludzkich przeżyć. Wyczuwamy w tekście immanentnie obecną ekspresywność jako podstawową cechę stylu kobiecego, nasycenie tekstu elementami wartościującymi.

1. Pierwszą, stosunkowo niewielką, grupę użyć przymiotnika красный stanowią wyrażenia odnoszące się do ustroju politycznego, jego atrybutów oraz członków aparatu władzy. Można więc spotkać zwroty typu: красныe комиссары, красные командиры, орден Красной Звезды, орден Красного Знамени, красный уголок, Красная Армия. W większości tego typu zwrotów przymiotnik красный wchodzi w skład nazw realioznawczych, a w aspekcie komunikatywno-pragmatycznym (tj. takim, który uwzględnia funkcje języka i wypowiedzi oraz możliwości oddziaływania na odbiorcę) są one nastawione przede wszystkim na informatywność, np.:

Около Днепра ночью при луне мне вручили орден Красного Знамени [Алексиевич 2005];

Через два дня после того, как мы узнали, что кончилась война, у нас было собрание в красном уголке [Алексиевич 2005];

Наш партизанский отряд соединился с частями Красной Армии, и после парада нам сказали, чтобы сдали оружие и шли восстанавливать город [Алексиевич 2005]. 
Konteksty z wydźwiękiem wartościującym są $\mathrm{w}$ tej grupie użyć niezwykle rzadko spotykane, nр.: Полииаи ездили по деревням и проводили среди людей агитацию: красные комиссары не жалеют даже собственных детей. Они - чудовища [Алексиевич 2005].

2. Kolejne użycia przymiotnika красный tworzą zaledwie kilkuelementowy zbiór. Są to antroponim Красная Шапочка, chrematonim Красный Крест oraz toponim Красная площцадь. Wymienione nazwy, w odróżnieniu od tych, które pojawiły się $\mathrm{w}$ pierwszej grupie, nie są związane ze sferą polityki i panującym ustrojem. W tekście reportażu pojawiają się tylko czterokrotnie i występują $\mathrm{w}$ kontekstach pozbawionych konotacji uwarunkowanych obecnością koloratywu.

Obie przedstawione wyżej grupy użyć przymiotnika красный są grupami najbardziej neutralnymi, odgrywającymi najmniejszą rolę w kształtowaniu wspomnianych wcześniej centrów komunikatywno-pragmatycznych.

Jednak $\mathrm{w}$ większości analizowanych przykładów zaczerpniętych z reportażu $У$ войны не женское лицо obecność czerwieni jest wyraźnie ukierunkowana na wyeksponowanie wymienionych centrów komunikatywno-pragmatycznych. Centrów tych nie sposób jednoznacznie rozgraniczyć z uwagi na ich ścisłe wzajemne powiązanie, ale zwykle jedno z nich wysuwa się na pierwszy plan i w większym stopniu niż drugie podlega językowemu obrazowaniu. Na sposób przedstawiania w reportażu wojny i uwikłanej w spiralę wojny kobiety, na czytelniczą interpretację odbieranych treści, ma wpływ wiele czynników, a czerwień jest jednym ze współkreujących je ogniw.

3. Koncentrację na komunikatywno-pragmatycznym centrum związanym przede wszystkim z kobietą zauważamy w użyciu derywatu czasownikowego покраснеть. Warto przyjrzeć się szerszemu kontekstowi jego użycia:

Младший лейтенант Николай Белохвостик... Ой, смотрите, покраснела я вся, а уже бабушка. А тогда были молодые годы. Юные. Я думала... Была уверена... Что... Я никому не признавалась, даже подруге, что в него влюблена. По уши. Моя первая любовь... Может, и единственная? Кто знает... Я думала: никто в роте не догадывается. Мне никто раньше так не нравился! Если нравился, то не очень. А он... Я ходила и о нем постоянно думала, каждую минуту. Что... Это была настоящая любовь. Я почувствовала. Все знаки... Ай, смотрите, покраснела... [Алексиевич 2005].

Zacytowany fragment zwraca uwagę emocjonalnym stosunkiem do prezentowanej rzeczywistości. Czerwony rumieniec na twarzy jako reakcja wywołana wspomnieniem pierwszej miłości kreuje obraz nasycony kobiecą wrażliwością.

I kolejny cytat, w którym to czerwień notabene znów odnosi się do kobiecych policzków: 
Долго ехали, а потом еще долго шли пешком. Был мороз. Я шла и все время держала зеркальце: не обморозилась ли? К вечеру вижу, что обморозила щеки. До чего глупая была... Слышала, что когда обморозишь щеки, то они белые. А у меня красные-красные. Думаю, что пусть бы они всегда у меня были обмороженные. А назавтра они почернели... [Алексиевич 2005].

Przykład ten świadczy o kobiecym dążeniu do odnalezienia w wojennej zawierusze elementów zwykłego, codziennego życia z czasów pokoju. To pozornie prozaiczne, jak mogłoby się wydawać, przywiązywanie uwagi do piękna czerwonych policzków jest próbą kobiecego stworzenia chociażby namiastki normalności i powrotu do świata nieskażonego realiami wojny.

Takich przykładów znajdziemy w reportażu więcej, np.:

[...] это была девушка-снайпер, но она погибла. Это была Саша Шляхова. Она погибла в снайперском поединке. И что ее подвело - это красный шарф. Она очень любила этот шарф. А красный шарф на снегу заметен, демаскировка [Алексиевич 2005].

Podkreślenia wymaga tutaj również fakt, że w zaprezentowanych kontekstach kolor czerwony wartościowany jest przez bohaterki pozytywnie z perspektywy estetyczneј (очень любила этот шарф; пусть бы они всегда у меня были обмороженные, tj. czerwone), co w utworze Aleksijewicz jest zjawiskiem spotykanym okazjonalnie.

Obecność czynnika kobiecego w omawianym centrum komunikatywno-pragmatycznym jest widoczna w następujących przykładach:

После войны я несколько лет не могла отделаться от запаха крови, он преследовал меня долго-долго. Стану стирать белье - слышу этот запах, стану варить обед - опять слышу. Подарил мне кто-то красную блузочку, а тогда же это такая редкость, материала не хватало, но я ее не носила, потому что она красная. Вот этот цвет я воспринимать уже была не способна [Алексиевич 2005];

А пошила из красной материи блузку, по рукам у меня через день расползлись какие-то пятна. Волдыри. Ни красного ситца, ни красных цветов - роз или гвоздик, мой организм не принимал. Ничего красного, ничего цвета крови... У меня и сейчас ничего красного в доме нет. Не найдешь [Алексиевич 2005].

W wyrażeniach красная материя, красный ситеи, красные изеты - bez umieszczenia ich w szerszym kontekście zacytowanych zdań, kolor czerwony służyłby jedynie do charakterystyki określanego przedmiotu. Przeżycia wojenne bohaterek reportażu wpływają jednak na modyfikację znaczenia koloratywu, dzięki czemu w przytoczonych fragmentach funkcja ekspresywna wypowiedzi dominuje nad funkcją informatywną. Obecne w cytatach przywołanie obrazów sensorycznych modeluje przede wszystkim centrum komunikatywno-pragmatyczne związane z kobietą, ale pośrednio również to zwią- 
zane z wojną, gdyż właśnie uczestnictwo w jej wydarzeniach spowodowało przesunięcie niektórych zjawisk z płaszczyzny zwyczajności, powszedniości, normalności na płaszczyznę nieakceptowalności i niepowszedniości. Przykładowo czerwona tkanina nie jest już tylko zwykłym artefaktem, lecz poprzez asocjacje z krwią przywodzi na myśl traumatyczne przeżycia wojenne, cierpienie i śmierć.

Obrażenia cielesne, cierpienie, śmierć i zniszczenia są immanentnie wpisane $\mathrm{W}$ wojnę. $\mathrm{W}$ ogromnej mierze wszystkie te skutki działań wojennych również może wyrazić czerwień i jej asocjacja z krwią, przyczyniając się do maksymalnego rozbudowania drugiego centrum komunikatywno-pragmatycznego reportażu, a mianowicie wojny. Czerwień charakteryzuje między innymi szczegóły krajobrazu po bitwie:

Прибыли мы к Сталинграду... Там смертные бои шли. Самое смертельное место... Вода и земля были красные... [Алексиевич 2005];

Вся матушка Волга была в крови... [Алексиевич 2005];

Перед сумерками я вышла на берег: по Морскому каналу плыли бескозырки. Одна за другой. Бескозырки и большие красные пятна на волнах... Щепки какие-то... Это наших ребят где-то сбросили в воду... [Алексиевич 2005];

А урожай в тот год был небывалый, хлеба стояли высокие-высокие. Зеленая трава, солнце такое, а убитые лежат, кровь... Убитые люди и животные [Алексиевич 2005];

Весь горизонт был охвачен багровым заревом [...] Горит весь Смоленск... [Алексиевич 2005].

W aspekcie komunikacyjnym i pragmatycznym przytoczone przykłady pozwalają uzmysłowić sobie ogrom ofiar i zniszczeń, czerwień elementów krajobrazu (nр.: вода и земля были красные; Волга была $b$ крови; багровое зарebo) jest tutaj bardzo wymowna i odsyła nas przede wszystkim do skojarzeń ze śmiercią i siejącym spustoszenie ogniem. Okazuje się, że cierpią nie tylko ludzie, ale i przyroda:

И страдают там не только они (люди!), но и земля, и птицы, и деревья. Все, кто живут вместе с нами на земле. Страдают они без слов, что еще страшнее... [Алексиевич 2005].

Czerwień poprzez wskazanie na krew pojawia się ponadto przy opisie doznanych obrażeń, dopełniając naturalistyczny opis uszkodzonej ręki:

К последнему подползла, а у него рука совсем перебита. Болтается на кусочках... На жилах... В кровище весь... Ему нужно срочно отрезать руку, чтобы перевязать [Алексиевич 2005]. 
Czerwień w reportażu została też ukazana jako tworzący kontrast z czernią wyróżnik kolorystyczny czasów wojny:

Я что еще думаю... Вот послушайте. Сколько была война? Четыре года. Очень долго... Ни птиц, ни цветов не помню. Они, конечно, были, но я их не помню. Да-да... Странно, правда? Разве могут быть цветными фильмы о войне? Там все черное. Только у крови другой цвет... Одна кровь красная... [Алексиевич 2005].

W zacytowanym fragmencie kolor czerwony jest jedynym barwnym punktem na tle achromatycznej czerni, symbolizującej negatywne konotacje wojny. Okazuje się jednak, że przez pryzmat wartościowania i symbolicznego wydźwięku chromatyczna czerwień z achromatyczną czernią nie tworzą kontrastu, lecz wspólnie wyrażają ujemną ocenę rzeczywistości wojennej. Można zaryzykować stwierdzenie, że czerwień krwi w powyższym cytacie jest tym detalem, który intencjonalnie zwiększa ewaluację o zabarwieniu deprecjonującym.

Na koniec fragment, w którym czerwień skojarzona została ze zwycięstwem (warto zauważyć, że asocjat zwycięstwo nie pojawia się w zacytowanym wcześniej artykule hasłowym słowa-bodźca красный):

Так вот... В подарок к Новому, сорок шестому году мне выдали десять метров красного сатина. Я посмеялась: „Ну, зачем он мне? Разве после демобилизации пошью себе красное платье. Платье Победы". Как в воду глядела... [Алексиевич 2005].

Reasumując, w reportażu $У$ войны не женское лици kolor czerwony i bezpośrednio z nim kojarzona krew są przykładami elementów wpływających na obrazowe ukazanie doświadczeń wojennych i jednocześnie różnych stron kobiecej wrażliwości. To przykłady środków wyrażających szczegóły, a Aleksijewicz, określana mianem mistrzyni detalu, operuje nimi w sposób ukierunkowany. Czerwień jako detal wypełnia nie tylko funkcję przedstawieniową, ale jako część składowa wypowiedzi bohaterek reportażu w aspekcie komunikatywno-pragmatycznym współwarunkuje dominację funkcji ekspresywnej. Czytelnik z kolei, poza tym, iż otrzymuje ogrom konkretnych informacji dotyczących życia na froncie, wprowadzony zostaje w sferę indywidualnych odczuć bohaterek i sam - na swój sobie tylko właściwy sposób, na te treści reaguje. To, w jaki sposób uzewnętrzni się funkcja impresywna wypowiedzi, czy reakcją będzie, przykładowo, smutek, żal, oburzenie, empatia czy może jeszcze inne odczucia, pozostaje $\mathrm{w}$ sferze domniemania. Nie podlega jednak wątpliwości, że detale ukazywane z perspektywy przestrzeni osobistej bohaterek reportażu, ich indywidualnych przeżyć, rozszerzają swoje oddziaływanie na środowisko społeczne, uwrażliwiając odbiorcę na okrucieństwo doświadczeń wojennych, oddziałując na uczucia i myśli, wpływając na ogląd i ocenę wydarzeń historycznych. 


\section{Bibliografia}

Алексиевич С. 2005. У войны не женское мицо, электронный ресурс: http://lib.ru/ NEWPROZA/ALEKSIEWICH/zhensk.txt (dostęp 15.07.2017).

Караулов Ю. Н., Черкасова Г. А., Уфимцева Н. В., Сорокин Ю. А., Тарасов Е. Ф. 2002. Русский ассоицативный словарь, t. 1, Москва: Астрель.

Тутнер Г. Б. 2009. Прагматика, [w:] И. Т. Касавин (red.), Энииклопедия эпистемологии и философии науки, Москва: „Канон+”, РООИ „Реабилитация”, электронный реcypc: http:/ / enc-dic.com/enc_epist/Pragmatika-536.html (dostęp 10.06.2017).

Cap P. 2014. Interdyscyplinarność wspótczesnej pragmatyki języka, [w:] P. Stalmaszczyk, P. Cap (red.), Pragmatyka, retoryka, argumentacja, Kraków: Universitas, s. 161-176.

Gawarkiewicz R., Pietrzyk I., Rodziewicz B. 2008. Polski stownik asocjacyjny: $z$ suplementem, Szczecin: Print Group.

Grzegorczykowa R. 2010. Wprowadzenie do semantyki jezzykoznawczej, Warszawa: Wydawnictwo Naukowe PWN.

Kutrzuba A. 2015. Przeciwko ciemności. 7. Festiwal Conrada rozpoczęty, źródło elektroniczne: http://www.dziennik-literacki.pl/fotorelacje/410,Przeciwko-ciemnosci-7-Festiwal-Conrada-rozpoczety (dostęp 20.07.2017).

Literacki Nobel 2015 dla Swietłany Aleksijewicz. 2015. Źródło elektroniczne: https://www. newsweek.pl/swiat/literacka-nagroda-nobla-2015-swietlana-aleksijewicz/2061pp4 (dostęp 8.01.2018).

Literacki Nobel: Swiettana Aleksijewicz o sobie i swoich książkach. 2015.Źródło elektroniczne: http:/ / wyborcza.pl/1,75410,18992284,literacki-nobel-swietlana-aleksijewicz-o-sobie-i-swoich-ksiazkach.html?disableRedirects=true (dostęp 20.07.2017).

Ostałowska L. 2011. „Wszyscy zdradzili wojenne kobiety”. Rozmowa ze Swiettana Aleksijewicz, źródło elektroniczne: http://wyborcza.pl/1,75410,9504105,_Wszyscy_zdradzili_wo jenne_kobiety_Rozmowa_ze.html (dostęp 23.07.2017).

Pietrzyk I. 2008. Konotacje nazw barw w języku Rosjan i Polaków, [w:] R. Gawarkiewicz, I. Pietrzyk, B. Rodziewicz, Polski stownik asocjacyjny: z suplementem, Szczecin: Print Group, s. 261-277. 